\title{
Literary Translation and Loanwords: A Study of English and Igbo Translations of Franz Kafka's Brief an den Vater
}

\author{
Dr. Ihechi Obisike NKORO
}

Abia State University Uturu, Nigeria

\begin{abstract}
Multilingualism and multiculturalism have become so characteristic of our times that it is hard to come by a literary work that is strictly monolingual. Languages in contact influence each other in various ways. One language could be more influential than the other as a result of linguistic and non-linguistic factors. A language that is documented and enjoys a more privileged political, economic, cultural, or religious position is likely to be more influential than another language that lacks these qualities. Languages in contact often borrow words from each other though a language that is considered to be more prestigious than another is more likely to be the donor language less prestigious one. Loanwords are therefore common among languages in contact. Intercultural literary communication is mostly effected through translation. Due to Africa's colonial experience, literary translation practice in Africa often involves European languages, Arabic, and indigenous African languages. In Nigeria, the languages that have played significant roles in literary translation include English, French, German, Arabic, and indigenous Nigerian languages. Franz Kafka's Brief an den Vater which was written in German has been translated into English as Letter to His Father by Ernest Kaiser and Eithne Wilkins and into Igbo as Soro Okwu m maobu Leta (Ndi) Nna by Felicia Ibemesi. This paper sets out to study loanwords in the English and Igbo translations from a target reader's perspective.
\end{abstract}

Keywords: Kafka, German, translators, English, Igbo, Letter/Leta

\section{Introduction}

From ancient times, communication among speakers of different languages has continued to be effected essentially through interpretation and translation. While interpretation deals essentially with oral communication, translation deals with written communication. Translated literature usually form part of the literary corpora of many human societies especially the developed countries. The literature in international languages like English, Spanish, Portuguese, French, German, and Arabic are replete with translated literature. If no man is an Island, every literary culture starts to benefit from other cultures. Literature has been known to contribute immensely to the course of human history. Chapman (1973), while explaining the relationship between linguistics and literature, notes that "the literature of a language offers a corpus of material for linguistic study" (pp. 4-5). On his part, Aire (2002) in his Stylistic Study of Chukwuemeka Ike's Sunset at Dawn, points out:

Dr. Ihechi Obisike NKORO, senior lecturer, Ph.D., Department of Foreign Language \& Translation Studies, Abia State University Uturu, Nigeria. 
A close study of Sunset at Dawn shows that the words that make it up can be broken into two broad categories. The first comprises five distinct linguistic classes, while the second consists of four registers of the same language. (p. 80)

It is against this background that the present work sets out to study loanwords in the English and Igbo versions of Franz Kafka's Brief an den Vater (1953). The English version for the study, Letter to His Father (1966), was translated by Ernest Kaiser and Eithne Wilkins while the Igbo version for the study, Soro Okwu $m$ maobu Leta (Ndi) Nna was translated by Felicia Ibemesi in 2005. The perspective of the study is according to Akakuru (2009) that of a "textologist" in that we are interested, not just in literature, but in the textual process in general: How texts function, how they make meaning within a cultural setting and across cultural boundaries in translation (pp. 1-2). Nkoro (2014) notes that English language expands its vocabulary through many linguistic techniques including borrowing and adaptation (pp. 5-6). In addition, Ijioma and Ezeafulukwe (2015) show that loanwords are common in Igbo language as Igbo borrows from non-indigenous Nigerian languages such as English, French, Arabic, and from indigenous Nigerian languages such as Hausa, Yoruba, and Efik (pp. 87-89).

In what follows, we as ideal target readers, that is, readers who do not understand German, the source language, would study the loanwords in the English and Igbo versions to understand further the universal and typological (peculiar) undertones of loanwords in translated texts.

Contemporary Nigerian literature like African literature in general comprises literature written originally in non-African languages such as Achebe's Things Fall Apart (1958) and Soyinka's The Lion and the Jewel (1963), Fatunde's La Calebasse Cassee (2002), literature in indigenous Nigerian languages such as Fagunwa's Ogboju Ode ninu igbo (1938) translated into English by Soyinka as The Forest of a Thousand Daemons (1968) and into French from the Yoruba text as Le preux chasseur dans la forêt infestée de démons (1989) by Abioye amd Nwana's Omenuko (1963) and translated literature. The translated literature could be divided into three categories. The first category represents literature translated from non-Nigerian languages into non-Nigerian languages such as French translation of Achebe's Things Fall Apart (1958) by Ligny as Le Monde s'effondre (1966) and French translation of Soyinka's The Lion and the Jewel (1963) by Chuto and Laburthe-Tolra Le lion et la perle (1977). The second category of translated Nigerian literature has to do with literature translated from indigenous Nigerian languages into non-Nigerian languages such as Nwana's Omenuko translated into French by Anyaehie as Omenuko: Le feu et le cendre (1995), Obakhena's Igbo-English Anthology Olisa Amaka (2001) and Ajiboye's French translation of Okedeji's Rere Run (1973) as Catastrophe au rendez-vous (2003). The third category of translated Nigerian literature has to do with literature translated from non-Nigerian languages into Nigerian languages such as Igbo translation of Moliere's Femmes Savantes by Ezeh as Filamint Na Ndi Otu Ya (1998) and Kafka's German text Brief an den Vater (1956) translated from German into Igbo by Ibemesi as Soro Okwu m maobu Leta (Ndi) Nna (2005), chosen for the study; belong therefore to the category of Nigerian literature translated from non-Nigerian languages into Nigerian languages. Writing on the need for mother tongue literatures in Nigeria, Nwachukwu-Agbada (2003) observes:

...education in MT even for the adult is more permeating, more retainable and more permanent in one's consciousness... For instance, the education of the rural populace in the mother tongue has been found to be necessary if the people are to contribute meaningfully to nation-building strategies... (p. 10)

We see Ibemesi's efforts to translate a German work into Igbo language as a timely response to the call of many Nigerian linguists such as Bam.gbose (2003, p. 84) for the production of literary works in African 
languages to enable the masses both oral and written literature in their own languages to be better equipped for African development.

\section{Loanwords}

Loanwords or borrowed words are such a common feature of languages in contact. It has been observed that scarcely can one pick any book, original or translated in which loanwords do not occur. For instance in non-translated works like Azurdia III (1977), the loanwords "sine qua non" are used as part of the title of the sixth chapter of his book thus: "The Sine Qua Non of Gospel Preaching” (p. 97). Again Amamihe (2004), the title of an Academic Journal written in English first draws the attention of the reader to an Igbo loanword "Amamihe". In addition, Njoku (2002), in his study "Imperial Religions in a Fractured Land: The Structural Roots of Religious Hubris in Nigeria", uses a Latin loanword in the title (p. 270). Furthermore, in translated literature like Marcela's Papeluche translated from Chilian into French, the title is a loanword while Koller's Laissez-moi mon dragon! translated from American English into French, shows that the word "dragon" that occurs in the title is a loanword. Akmajian, Demers, Farmer, and Harnish (2009) indicate that another way to expand our vocabulary is to "borrow" words directly from other languages (p. 28) while Eke (2000) explains that there could be carbon copying (le calque) among languages (p. 12). According to him, carbon copying as the term implies refers to the total borrowing of the structure or sentence from another language. This borrowed structure is later translated into the target language.

\section{The Original Text and Its English and Igbo Versions}

The original German text Brief an den Vater written in 1919 by Franz Kafka (was first published posthumously in 1953 through the efforts of Kafka's friend, Max Brod. The German text edited by Brod Max and translated into English as Letter to His Father by Ernst Kaiser and Eithne Wilkins and published in 1966 in a Bilingual Edition by Schocken Books New York. An excerpt from this Bilingual Edition was used for the study. From the Publishers Note we learn that,

Kafka actually gave the letter to his mother to hand to his father, hoping it might renew a relationship that had lost itself in tension and frustration on both sides... Probably realizing the futility of her son's gesture, the mother did not deliver the letter, but returned it to the author...

The Igbo text studied Soro Okwu m maobu Leta (Ndi) Nna is an abridged form of the German text Brief an den Vater translated by Felicia Ibemesi. In her Igbo translation, Soro Okwu m (N'akuko ndi ozo...) published in 2005 by CIDJAP Press, Enugu, Felicia Ibemesi presents a collection of short stories by Franz Kafka and an abridged Igbo version of Brief an den Vater/Soro Okwu m maobu Leta (Ndi) Nna. Although the English version is a full-length equivalent of the German text Brief an den Vater, the Igbo version is an excerpt/an extract/an abridged form of the German text. Our comparison of loanwords in the English and Igbo translations would therefore be limited to where the Igbo text stops. Franz Fafka's feeling of inferiority and paternal rejection is captured vividly in the Igbo and English versions, hence our desire to study how the English and Igbo translators handled loanwords in reproducing Kafka's message expressed in German in English and Igbo. It should be noted that there are other English versions of Brief an den Vater such as Dearest Father translated by Hannah and Richard Stokes and published by Oneworld Classics in 2008 whereas Ibemesi's translation is the only Igbo 
version known to us. Though Shutteworth and Cowie (1997, pp. 98-99) among others, have in the recent past listed "Machine-aided Translation (MAT)" and "Machine Translation or Automatic Translation (MT)" as modern additions to the traditional practice of translation effected essentially by man, the versions understudy are translated by humans. The thoughts expressed hereafter would therefore be restricted to translation by humans. Like Landers (2001) who while reflecting on a day in the life of a literary translator, "It may be useful to get inside the head of a literary translator as he thinks aloud, or at least grapples with the moment-to-moment problems attendant to translating a work of fiction..." (pp. 38-40), we intend to travel into the literary translator's saga with intercultural communication through the translator's choice of loanwords. Wardhaugh's (2010, p. 90) study indicates "frequent borrowings in Luxembourg from French and German into Luxemgurgish" beccause these three languages have been official languages since 1984. Chakalov (1977, pp. 74-76) shows that certain "Foreign-born" English words and phrases are typical of social and economic relations in the countries of Eastern Europe while Bliss' A Dictionary of Foreign Words \& Phrases in Current English (1987) indicates that loanwords are indices of intercultural communication. Given that borrowing according to Kemmer (2010, 2013, p. 1) is "a consequence of cultural contact between two language communities" and since Poplack, Sankoff, and Miller (1988, p. 69) and Haspelmath (2007, p. 2) point out that lexical borrowing which could be massive often follows a pattern, in what follows we shall attempt to investigate the pattern of lexical borrowing as represented by the loanwords that appear in the English and Igbo versions vis a vis the translators and the target readers and their environments.

Table 1

Loanwords in Letter to His Father and Soro Okwu M Maobu Leta (Ndi) Nna

\begin{tabular}{lll}
\hline $\mathrm{S} / \mathrm{N}$ & $\begin{array}{l}\text { Loanwords in English version } \\
\text { (Letter to His Father) }\end{array}$ & $\begin{array}{l}\text { Loanwords in Igbo version } \\
\text { (Soro Okwu M Maobu Leta...) }\end{array}$ \\
\hline 1 & Franzensbad (p. 9) & Franzensbad (p. 11) \\
2 & Ottla (p. 9) & Ottla = p. 11 \\
3 & Robert Kafka, Karl Hermann (p. 11) & Robert Kafka, Karl Hermann (p. 13) \\
4 & Lowyish spur (p. 11) & -Lowy omitted in Igbo text. \\
5 & Phillipp, Ludwig and Heinrich (p. 13) & Philip, Ludwig na Heinrich (p. 14) \\
6 & Valli (p. 13) & Valli (p. 14) \\
7 & Felix (p. 15) & Felix (p. 15) \\
8 & Pavlatche (p. 17) German = pawlatsche & Absent \\
9 & Pepa (p. 19) & Pepa (p. 17) \\
10 & Beer (p. 19) & biaa (p. 17) \\
10 & Meshugge (p. 21) & Meschuge (p. 19) \\
11 & The Yiddish actor Lowy (p. 25) & Absent \\
12 & Vermin & Absent \\
13 & ado (p. 25) & Absent \\
14 & Vinegar (p. 27) & Viniga (p. 21) \\
15 & -Absent & Leta (p. 10) \\
16 & Absent & Baakwomi \\
17 & Absent & Tempuul (p. 11) \\
18 & Absent & Tikeeti , tiyeta (p. 11) \\
19 & Absent & tiyeta (p. 11) \\
20 & Absent & froko (p. 16) \\
\hline
\end{tabular}


(Table 1 continued)

\begin{tabular}{lll}
\hline S/N & $\begin{array}{l}\text { Loanwords in English version } \\
\text { (Letter to His Father) }\end{array}$ & $\begin{array}{l}\text { Loanwords in Igbo version } \\
\text { (Soro Okwu M Maobu Leta...) }\end{array}$ \\
\hline 21 & Absent & ami (p. 17) \\
22 & Absent & plank (p. 18) \\
23 & Absent & Kabin (p. 18) \\
24 & Absent & Tebuul (pp. 20-22) \\
25 & Absent & Breedi (pp. 21-22) \\
26 & Absent & Pensuul (p. 22) \\
\hline
\end{tabular}

\section{Discussion}

The Table 1 of loanwords and expressions above indicates there are three main categories namely: direct or full loanwords and expressions, partially adapted loanwords and expressions, and fully adapted loanwords and expressions. In what follows, we would try to highlight each of these categories and how they function in the English and Igbo versions.

\section{Direct or Full Loanwords and Expressions}

Franzensbad (p. 9), p.11 (Igbo)

Proper Names: Ottla (p. 9, 11), Robert Kafka, Karl Hermann (p. 11), p. 13 = Igbo

Phillipp, Ludwig and Heinrich (p.13/14), Valli (p.13/14), Felix (p.15/15), Pepa (p.19/17)

Maintained as in the original German text in both versions for stylistic reasons or Local colouring (full loaning or direct)

The loanwords listed above are direct transfer of words of one language into another without any structural, segmental, or suprasegmental alterations. This is common in both literary and non-literary writings as could be seen in Ajunwa (2004) and Reinold (2012, p. 1).

Examples:

(1) “Good- morning, Ada. How are you?" (Ajunwa, 2004, p. 39).

(2) The most important market in our own area was called Orie-Ukwu (Ajunwa, 2004, p. 75).

(3) Scapula exercises are very common and usually a needed component to any rehabilitation or corrective exercise program (Reinold, 2012, p. 1).

In the above examples, the Igbo proper nouns "Ada" and "Orie-Ukwu" as well as the Latin proper noun "scapula" have been reproduced verba tim or without any structural deformation in English. This same category of loanwords therefore exists both in the English and Igbo versions of the German text studied. All the proper nouns in the German text in the English and Igbo versions are retained without any alteration thereby reproducing the German touch of the original text.

\section{Slightly Adapted Loanwords Found in English and Igbo Versions}

The second category of loanwords identified in the versions studied represents loanwords which are slightly adapted to English and Igbo by removal of a consonant. Only one instance of this, that is, "Meschugge" (German, p. 20), Meshugge (English, p. 21) and Igbo "Meschuge" (p. 19). It is noteworthy that the Hebrew word "měshuggä", which according to Microsoft Encarta became "meshuge" in Yiddish evolved in the 19th Century to become "Meschugge" in German. The English "Meshugge" and the Igbo "Meschuge" testify of the continuous evolution of the Hebrew cognate or original word even through literary translation. 


\section{Fully Adapted Loanwords Found in English and Igbo Versions}

Here the loanwords undergo so much orthographic changes that one or more consonants or vowels may be deleted from the source word/cognate so as to fit into the structure of the target language.

Examples:

(1) Vinegar (English, p. 27)/viniga (Igbo, p. 21)

(2) Beer (p. 19, English), biaa (p.17, Igbo) German = Bier

Microsoft Encarta (2009) explains that the English word "vinegar" (sour wine) is derived from the Latin word "vinum acre" via the French word "vyn egre". As seen in the Igbo text, this has been borrowed into Igbo as "viniga" (p. 21). The English loanword "Beer" is derived from Latin biber (drink)/bibera (to drink) while the Igbo loanword "biaa" is derived from English "beer".

\section{FullyAdapted Loanwords Found in English Version Only}

Another category of loanwords fully adapted to the structure of the target language identified in the study has to do with which occur only in the Enlish version but does not occur in the Igbo version.

Examples:

(1) Pavlatche (p. 17)

(2) Vermin? German =,

The word "pawlatsche" occurs in the German text, while it occurs as "Pavlatche" (p. 17) in the English text. From the Publishers Note of the Bilingual Edition of The Letter to the Father used for this study we learn that "Pavlatche is the Czech word for the long balcony in the inner courtyard of old Austrian houses". As for the English loanword, Microsoft Encarta (2009) indicates that it is derived from Latin "vermis" (worm) via old French "assumed Vulgar Latin verminum "noxious life forms"”.

\section{FullyAdapted Loanwords Found in Igbo Version Only}

This category of loanwords fully adapted to the structure of the target language identified in the study has to do with which occur only in the Igbo version but does not occur in the English version.

Examples:

(1) Leta (p. 10)

(2) baakwomi (p.10)

(3) Tempuul (p. 11)

(4) Tikeeti , tiyeta (p. 11)

(5) froko (p. 16)

(6) ami (p. 17)

(7) Tebuul (pp. 20-22)

(8) Breedi (pp. 21-22)

(9) Pensuul (p. 22)

With the exception of example (2) "baakwomi" which is a loan expression from Hausa, all the other Igbo loanwords listed above are borrowed from English and adapted to the Igbo phonological system. Although there is an attempt to fuuly adapt the loanwords to conform with the phonemic structure of most Kwa languages like Yoruba and Igbo whose words end in vowels, this was not totally achieved. Spoken and recorded adaptations 
seen in recent studies such as Nwajiuba et al. (2006), Omachonu (2009), Ayeleru (2011), and Ohaike (2013) prove Ibemesi's conscious efforts in this regard.

Examples

(1) Bible /ibaibulu/, school /ichekwulu/ (Omachonu, 2009, p. 135).

(2) .../okuko Anak "broila", .../oganoleptic, .../hepatozik, .../faitokemikalu, .../zobo (Nwajiuba et al, 2006, pp. 4-6).

(3) boys/boisi, AIDS/eedi (Ayeleru, 2011, pp. 118-119).

(4) korikulum, Nashional, Polisi, Edukeshion, goomenti, sobjekti (Ohaike, 2013, p. 96).

\section{Conclusion}

The history of living or dead languages reveals certain evolutionary trends of linguistic communities. As people migrate from one linguistic community into another and as individuals come into contact with different languages in their saga on earth, they share part of their learning's through their language use. No modern language is known to operate single-handedly limiting itself to only its own original words but accesses knowledge through a cross-fertilization of ideas from various cultures as depicted in the existence of loanwords and expressions. This study compared loanwords and expressions in the English and Igbo versions of Franz Kafka's Letter to His Father and Soro Okwu m Maobu Leta (Ndi) Nna. The original text Brief an den Vater was written in German. Hence, the first stage of the comparison runs between German and English which are both members of the Indo-European language family while the second stage of the comparison runs between German and Igbo, that is, between a European language and an African language of the Kwa group of the Niger Congo family. Each of the versions studied point to both general and personal tendencies of translators in their use of loanwords and expressions.

Furthermore, German proper nouns and especially names of persons are retained in the two versions as the translator's maintain local German colour through this. It is equally for this same reason that the German word "frazensbad" is retained in the two versions. Again, the loanword "pavlatche" which occurs in the English version only, which is explained in the Publisher's note to be of Czech origin and which is written in the German text as "pawlstche", shows that the English translators borrowed the Czech word directly to point to a measure of linguistic affinity between the Czechs and the English. Furthermore, the loanword "Meshugge" (English version) loanword "meschuge" (Igbo version) which is written in the German text as "meschugge", according to Encarta Dictionary 2009, is said to be of Yiddish and Hebrew origin. This then means that the original German text testifies further of loanwords. Apart from the above loanwords which are common to both versions, majority of the other loanwords are restricted to the Igbo text. These include: tiyeeta, ticketi, tebulu, pensul, etc., which are borrowed from English into Igbo. The loan expression "baakwomi" which is of Hausa origin but adapted to Igbo points to nigerianizaion of the text as the translator carries the reader down to the home front through that humorous expression of high communicative effect.

Whle we agree wth Akachi-Ezeigbo cted by Azodo (2014, p. 368) that the translation of Achebe's Things Fall Apart into some African languages is a positive development, our study shows that literary translation into African languages does not only enhance intercultural transfer of knowledge but provides corpus for linguistic research. To conclude, we would say that loanwords and expressions are part of the artistic inventory of the writer 
or translator which not only gives an historic undertone to a literary piece but helps the artist to create humour in an attempt to localize the message.

\section{References}

Achebe, C. (1958). Things fall apart. London: Heinemann.

Achebe, C. (1966). Le monde s'effondre (Things fall apart.). (M. Ligny, Trans.). Paris: Présence Africaine.

Aire, V. O. (2002). A stylistic appraisal of Chukwuemeka Ike's sunset at dawn. In V. O. Aire (Ed.), Selected essays and reviews on African literature and criticism (pp. 79-89). Jos: St Stephen Book House Inc..

Ajunwa, E. (2004). Destined to survive/Destiné à survivre (Bilingual novel). Enugu: Enovic Publishers Co., Ltd..

Akakuru, I. A. (2009). Conversations with a critic. Port Harcourt: Pearl Publishers.

Akmajian, A., Demers, R. A., Farmer, A. K., \& Harnish, R. M. (2009). Linguistics: An introduction to language \& communication (5th ed.). New Dehi: PHI Learning Private Limited.

Amamihe. (2004). Journal of Applied Philosophy, 2.

Ayeleru, B. (2010/2011). The Muse of language: The Ijio-Gelede innovation. Abudof: Journal of Humanities, 1.9/10(September), 112-121.

Azodo, A. U. (2014). On African cultures, literatures and languages: Interview with Akachi Adimora-Ezeigbo. In E. A. Adedun and O. B. Nweke (Eds.), New perspectives on a literary enigma: A festschrift in honour of professor Theodore Akachi Adimora-Ezeigbo (pp. 360-369). Ibadan: University Press Plc.

Bamgbose, A. (2003). Language as a factor in participation and exclusion. In O. M. Ndimele (Ed.), Four decades in the study of languages \& linguistics in Nigeria: A festschrift for Kay Williamson (pp. 71-88). Port Harcourt: National Insttute for Nigerian Languages $\mathrm{Aba}, \& \mathrm{M} \& \mathrm{~J}$ Grand Orbt Communcations.

Bliss, A. (1987). A dictionary of foreign words \& phrases in current English. London: Routledge \& Kegan Paul Ltd..

Chapman, R. (1973). Linguistics \& literature: An introduction to literary stylistics. London: Edward Arnold Publishers.

Eke, L. K. (2000). A handbook of translation practice (English-French). Abakaliki: Willyrose \& Appleseed Publishing COY.

Fagunwa, D. O. (1938). Ogboju Ode ninu igbo irunmole et autres du genre fantastique (The forest of a thousand daemon). London: Nelson.

Fagunwa, D. O. (1968). The forest of a thousand daemons. (W. Soyinka, Trans.). Lagos: Nelson.

Fagunwa, D. O. (1989). Le preux chasseur dans la forêt infestée de démons (The forest of a thousand daemons). (O. Abioye, Trans.). Nelson: Total Nigeria Ltd..

Fatunde, T. (2002). La Calebasse Cassee (The broken calabash). Ibadan: Bookcraft Ltd..

Haspelmath, M. (2007). Loanword typology: Steps toward a systematic cross-linguistic study of lexical borrowability. Retrieved from http://www.eva.mpg.de/lingua/staff/haspelmath/pdf/LWT.pdf

Ijicma, P. N., \& Ezeafulukwe, O. (2015). Loanwords: The case of Igbo language. Nigerian Languages Studies (NILAS): A Journal of The National Institute for Nigerian Languages, Aba, 2(3), 83-91.

Kafka, F. (1966). Brief an den Vater/Letter to his father (Bilingual ed.). (E. Kaiser \& E. Wilkins, Trans.). New York: Shockem Books.

Kafka, F. (2005). Brief an den Vater/Soro Okwu m maobu Leta (Ndi) Nna. Soro Okwu M (N'akuko Ndi Ozo...) (Letter to his father). (F. Ibemesi, Trans.). Enugu: CIDAP Publishers.

Kafka, F. (2008). Dearest father. (H. Stokes \& R. Stokes, Trans.). Surrey: Oneworld Classics. Retrieved from $\mathrm{http} / / / \mathrm{www}$. almaclassics.com/excerpts/dearestfather.pdf

Kemmer, S. (2013). Loanwords: Major periods of borrowing in the history of English. Words in English Public Website, Ling/Eng 216 Course Information, Rice University. Retrieved from http://www.ruf.rice.edu/ kemmer/Words/loanwords.html

Koller, J. F. (1998). Laissez-moi mon dragon! (A dragon in the family!). (S. Lamoine, Trans.). Paris: Editions Pocket Jeunesse.

Landers, C. E. (2001). Literary translation: A practical guide. Clevedon: Multilingual Matters Ltd..

Lefevere, A. (1983). Literature: Comparative and translated. Babel, 2(XXIX), 70-75.

Marcela, P. (1997). Papelucho. (J. P. Duviols, Trans.). Paris: Editions Pocket.

Microsoft Encarta. (2009).

Moliere, P. (1971). Les femmes savantes (The learned ladies). Paris: Larousse.

Moliere, P. (1998). Filamint Na Ndi otu Ya (Les femmes savantes). (P. J. Ezeh, Trans.). Onitsha: Noble Publishers. 
Njoku, C. A. (2003). Imperial religions in a fractured land: The structural roots of religious hubris in Nigeria. In T. I. Okere (Ed.), Religion in a world of change: African ancestral religion, Islam and Chritianity (pp. 270-285). Owerri: Whelan Research Academy.

Nkoro, I. O. (2014). English words of nautical origin: Implications for Terminological Research in Igbo Language. Africana Studies Review: The Journal of the Center for African and African American Studies, 4(1), 1-15.

Nwachukwu-Agbada, J. O. J. (2003). Language and national development: The case for mother tongue and mother-tongue literatures in education. Journal of Nigerian Languages and Culture, 5(March), 5-12.

Nwajiuba, C., Asonye E., Chukwukere, F., \& Nwajiuba C. (2005). An exploration of the problems and prospects of scientific publication in Igbo language. Journal of Nigerian Languages and Culture, 7(September), 1-8.

Nwana, P. (1963). Omenuko (Official Orthography ed.). Ikeja: Longman.

Nwana, P. (1995). Omenuko: Le feu et la ceindre (Omenụkọ). (E. O. Anyaehie, Trans.). Okigwe: Fasmen.

Obakhena, R. E. (Ed.). (2001). Olisa Amaka: An anthology of Igbo written poems, English version inclusive for both L1 and L2 language students in postprimary and tertiary institutions. Ibadan: Claverianum Centre.

Ohaike, N. (2013). Ntughari di ka Uzo e Si Ewulite Mba na Asusu (Translation as a means of National and Language Development). Journal of Translation Studies and Research (Jotransar), 1(1), 92-98.

Okediji, O. (1973). Rere run. Ibadan: Onibonje Press \& Book Industries (Nig.) Ltd..

Okediji, O. (2003). Catastrophe au rendez-vous (Tragic appointment). Ibadan: Heinemann Educational Books (Nigeria) Plc.

Omachonu, G. S. (2009). Assimilation and syllable structure process in Igala. Kiabara: Journal of Humanities, 15(2), 125-140.

Poplack, S., Sankoff, D., \& Miller, C. (1988). The social correlates and linguistic processes of lexical borrowing and assimilation. Retrieved from http://albuquerque.bioinformatics.uottawa.ca/Papers/JournalPublication/1988_Poplack_Sankoff.pdf

Reinold, M. (2012). 3 myths of scapula exercises. Retrieved from http://www.mikereinold.com/2012/11/3-myths-of-scapula-exercises.html

Soyinka, W. (1963). The lion and the jewel. Ibadan: Oxford University Press.

Soyinka, W. (1977). Le lion et la perle (The lion and the jewel). (J. Chuto \& P. Laburthe-Tolra, Trans.). Yaoundé: CLE (nouvelle édition).

Wardhaugh, R. (2010). An introduction to sociolinguistics (6th ed.). West Sussex: Wiley-Blackwell. 